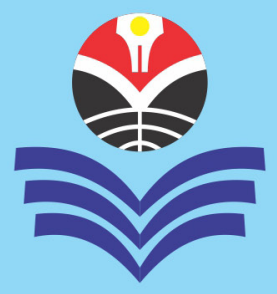

\title{
Ideal Certification of Visual Arts in Nigeria through Valid Practical Assessment
}

\begin{abstract}
The inappropriate practical assessment of the Visual Arts for ideal practical evaluation has necessitated the general outcry on the factors responsible for it. This paper tries to investigate the factors responsible for the non-compliance with credible practical assessment in Visual Arts for quality certification. It is giving some insight into solutions that will help in stamping out these inhibiting factors against the credible practical assessment in Visual Arts. When more emphasis are laid on practical courses and standard practical test examination conducted, it will go a long way in solving the unemployment problem observed as possible fallout of assessment methods and emphasis paper qualification at the expense of practical practice. It is suggested that examination materials be provided at least a month to the commencement of examination, more time should be allotted to practical examinations, supervision of practical examination should be handled with more seriousness, and the joint assessment of practical examination works be introduced. Finally, it is recommend possible ways of conducting practical examination to all stake holders in Visual Arts in Nigeria. KEY WORD: Practical Assessment; Visual Arts; Quality Certification; Examination Materials; National Development of Nigeria.
\end{abstract}

ABSTRAKSI: "Sertifikasi Ideal Seni Rupa di Nigeria melalui Penilaian Praktek yang Valid". Penilaian praktek Seni Rupa yang tidak tepat untuk evaluasi praktek yang ideal mengharuskan terjadinya kecaman umum terhadap faktor-faktor yang bertanggung jawab terhadapnya. Makalah ini mencoba untuk menyelidiki faktor-faktor yang bertanggung jawab atas ketidakpatuhan terhadap penilaian praktek yang kredibel dalam Seni Rupa untuk sertifikasi mutu. Ianya memberikan beberapa wawasan tentang solusi yang akan membantu dalam mencegah faktor penghambat terhadap penilaian praktek yang kredibel dalam Seni Rupa. Bila penekanan lebih diberikan pada kursus praktis dan ujian praktis standar yang dilakukan, ia akan sangat membantu dalam memecahkan masalah pengangguran yang diamati sebagai kemungkinan dampak metode penilaian dan penekanan pada kualifikasi kertas dengan mengorbankan ujian praktek. Disarankan agar bahan ujian diberikan paling sedikit sebulan sampai dengan dimulainya ujian, lebih banyak waktu yang harus diberikan untuk ujian praktek, pengawasan terhadap ujian praktek harus ditangani dengan lebih serius, dan penilaian bersama terhadap latihan ujian praktek diperkenalkan. Akhirnya, direkomendasikan berbagai cara melakukan ujian praktek untuk semua pemangku kepentingan Seni Rupa di Nigeria.

KATA KUNCI: Penilaian Praktis; Seni Rupa; Sertifikasi Mutu; Bahan Ujian; Pembangunan Nasional Nigeria.

About the Authors: D.N. Osariyekemwen, Ph.D. is a Lecturer at the Department of General Art and Industrial Design, Auchi Polytechnic, PMB 13, Auchi, Nigeria; P.O. Otimeyin, Ph.D. is a Lecturer at the Department of Ceramics, Auchi Polytechnic, PMB 13, Auchi, Nigeria; and G.O. Esebameh is a Lecturer at the Department of Graphics and Textiles, Auchi Polytechnic, PMB 13, Auchi, Nigeria. E-mails address of authors: osadanosa@gmail.com, otimeyinpius@yahoo.com, and continentalgeobameh@gmail.com

How to cite this article? Osariyekemwen, D.N., P.O. Otimeyin \& G.O. Esebameh. (2017). "Ideal Certification of Visual Arts in Nigeria through Valid Practical Assessment" in MIMBAR PENDIDIKAN: Jurnal Indonesia untuk Kajian Pendidikan, Vol.2(2), September, pp.155-162. Bandung, Indonesia: UPI [Indonesia University of Education] Press, ISSN 2527-3868 (print) and 2503-457X (online).

Chronicle of the article: Accepted (April 6, 2017); Revised (June 13, 2017); and Published (September 30, 2017). 


\section{INTRODUCTION}

TVET (Technical and Vocational Education and Training), which is the pivotal skill acquisition certification, has been taken as the key to unlocking the store house of the technological and economic growth of any nation. Therefore, attention and time must be given to the conduct of practical examinations leading to the acquisition of appropriate skills, abilities and competences for a quality, and credible practical certification (Baker, 2008; and Darling-Hammond et al., 2013).

Practical examination remains a proficiency test of skills, a test of one's knowledge, ability, and aptitude to do something well. In most cases, the student is required to exhibit manual dexterity in a given task as a sign of competence. The nature of the Visual Art programme dictates that more time be devoted to practical learning process, while the examinations could maintain good balance between theory and practical (Ibude et al., 2010; and Jockov, 2016). Such balance distinguishes the Fine and Applied Art Students from fellow workshop apprentice.

The students, in a formal learning environment like ours, are in their area of study, made to undertake some background theory that do not create room for the rather trial and error attitude of the road side artist. They have the in-depth understanding of what they do.

On the other hand, the art students should not just be theoretical persons who would not be able to practically express their ideas. We know it is ideas that move the world and not the products but when such ideas does not relate to products, they die with the owner. So, it is proper to translate all ideas into products through practical perfection of the materials. It means that more time be given the student artist to be practically competent.

\section{FINDINGS AND DISCUSSION}

Scholastic View on Practical

Examination Assessment. The main

objective of practical examination is the assessment of students' manipulative skills, the mastering of related technological information skills, the working habits, safety habits, and competence in the use of tools and equipment (Ibude et al., 2010; and Jockov, 2016). Proper assessment procedure in our institutions would enhance the production of special skilled manpower for our workforce.

O. Hornsby (2001) defined assessment as the act of judging or forming an opinion about somebody or something, while practical is connected with real situations rather than with ideas or theories (Hornsby, 2001). G.A. Badmus \& C.N. Omoifo (1998) opined that it is the process of investigating the status of individual or group, usually with reference to expected outcomes or criteria (Badmus \& Omoifo, 1998); while assessment to R.E. Stake (1969) involves the direct measurement of performance on important reference tasks (Stake, 1969).

Against the above backdrop, two important functions are performed when proper assessment procedure is observed: firstly, attention on the student's specific behavioural or attitudinal pattern to work for instance, the attitude towards wastage or otherwise of materials; and secondly, it provides a convenient method for recording or judging the perseverance of the student during the test (Messick, 1994; and Maxwell, 2001).

However, if on the spot correction, assistance, and assessment cannot be carried out, so also the working and safety habit exhibited by the student during the cause of executing the task could not be known to the lecturer, because most practical works are done from home and only the product assessment are observed to the detriment of the process assessment. At this point, it is worthy to note that some examiners are 
ignorant of the required process and the various practical assessments that will give rise to their checklist for accurate appraisal (Gipps, 1994; and Ibude et al., 2010).

This brings us to the three notable types of assessment which are: (1) Product assessment; (2) Process assessment, and (3) Product-process assessment. The description of assessment's types is following here ( $c f$ Black \& Dylan, 1998; Baker, 2008; Mussawy, 2009; and Ibude et al., 2010).

Firstly, Product Assessment. This is the procedure of examining the finished practical works using the appropriate checklist. In this case, the finished practical work product must tally with the specification given; the practical art works are taken away from the point of production for assessment.

Secondly, Process Assessment. This is the process required by the examiner/ lecturers to verify the step by step procedures of carrying out the practical works before attainment of finished work in an examination/workshop. The assessor or lecturer is expected to be physically present to see every student performing the step by step operation of his or her task and rating of the student is done on the spot (process) with the help of checklist. The finished practical work is not carried away for assessment.

The process assessment requires that the practical work is carried out in the presence of the lecturer. The students' performs the step by step operation of the practical task with the lecturer physically present to rate students' on the spot (process) performances. The lecturer is able to see the students as they observe the process of work; how they were able to manipulate and master the use of materials. The economy of time and safety habit of the students is also assessed. It involves systematic assessment of work at different stages.

Thirdly, Product-Process Assessment. This is where students are rated based on the practical finished work and the step by step operation of task performance using the checklist. This is where the lecturer physically monitors the processes that lead to the final product of practical work. This might take some days of assessment by the examiner, as such patience is required.

Based on the above types of practical assessment, it is proper to adopt the product-process assessment of students by lecturer, because it provides two important ingredients (Park, 2003; and Taylor \& Tyler, 2012). First, it focuses attention on the students' psychomotor skill, affective, and cognitive domain which has to do with the students' attitudinal and behavioural pattern with response to how student manages the use of materials in order to provide comparative judgement on the finished work. Second, quality certification derived from practical examinations would become possible only when such issues as non provision of examination materials, insufficient timing, inadequate supervision, poor assessment process of practical works, and the likes are handled with caution.

\section{Studies on Non-Provision of Practical} Examination Materials. The non-provision of adequate practical examination materials by the leadership of the institutions do not allow students to put in their very best. Examination is a tool for determining the level of student's ability after the teaching process. According to G. Adewale (2004), examination is the series of questions asked in order to determine, whether or not the student have mastered what they are supposed to acquire (Adewale, 2004).

Practical examination requires that the needed materials are made available before such an examination commences. Teaching aids and materials, according to K.A. Ughamadu (1998), make education more productive. It also helps to speed up the rate of student's learning (Ughamadu, 1998). Group work during practical examination has become the order of the day, because 
practical examination lacks adequate practical materials. Such group works should not be allowed in practical examinations, because this only allow brighter students to work for the benefit of all and also prevent proper assessment of each student's manipulative skills, mastery skills, working and safety habits, and competence in the use of tools and materials etc.

When cheap and substandard materials are provided for practical examination works, it removes proficiency from final project and prevents the student's demonstration of craftsmanship. For instance, the use of poster colour as substitute in an examination requiring water colour will definitely not yield the desired transparent effect that the water colour would give on paper. So also is the use of cartridge paper in a painting examination requiring a cardboard paper, the technical skill will suffer. Such provision of inadequate practical materials leads to miniaturization of examination end products, which in most cases are neither useful nor functional. It is, therefore, proper that adequate examination practical material are supplied as at when required (Park, 2003; and Taylor \& Tyler, 2012).

What should immediately follow after the moderation of every practical question in visual art is the listing of needed materials (cutting list), that is the materials required for the examination; this should be prepared and sent to the Chief Executive or Head of the institution at least a month to the commencement of examination. The list should spell out the types of materials, required quantity and quality, and possibly, cost of the items.

Views on the Insufficient Timing of Practical Examinations. Time is a major consideration in the proficiency test of students' skills, especially in practical examinations. The amount of time allotted to such courses matters a lot. Sufficient time should be given not only during examinations, but also during learning so as to devote significant time to preparing the students for practical examinations (Messick, 1994; Maxwell, 2001; and Mussawy, 2009).

Since the time allotted to practical courses in the visual arts is far short of what is desired as a result of the total work load of students, due to the increasing number of General (GNS) courses, practical courses that would ordinarily be class work or studio practise to be completed in the presence of the lecturer are most times given as take home assignment for lack of an adequate amount of practical hour within the school study's period. What most time, would have being seen done by the students and immediately corrected and assessed by the lecturer, are given to students as take home assignment which most probably are contracted out to external touts.

Reappraiser of Poor Assessment Process of Practical Work. Assessing practical test can better be carried out than it is currently done, following carefully planned and implemented assessment techniques that will ensure that the evaluation processes provide the right information about the student's learning (Messick, 1994; Maxwell, 2001; and Mussawy, 2009). Practical work assessment helps to establish student's principles of performing the required action of psychomotor skill, which is the only way for the nation's technological breakthrough.

In fact, the acquisition of the acceptable, adequate skills, abilities and competences, both mental and physical by the student, will equip the examinee to live a self reliant life and contribute to the technological advancement to our great nation. There is no known standard way of assessing student's practical works. What you find is the individual way of practical assessment. It is, therefore, important that Visual Art teachers are familiar with the major objectives in the subject area and to practice these objectives in order to ensure accurate assessment of 
students' potentials (Osariyekemwen, 2003).

The latter will be possible if there is a credible practical examination assessment, especially in Visual Arts where examiners/ lecturer are made to adhere strictly to the checklist/marking scheme as model guard for assessment. Every assessment should have a reference point, this according to W.A. Mehrens \& I.J. Lehmann (1975), should be consistent from one student to another and in everyday practice is referred to as the marking scheme, which according to J.N. Odili \& E.P. Oghuvhu (2008) are what the assessor expects from the student. It shows the expected answers and the mark obtainable (Mehrens \& Lehmann, 1975; and Odili \& Oghuvhu, 2008).

\section{Practical Examination and its}

Inadequate Supervision. One may think that practical examination do not require close supervisions. This is a misconception which we must told because, one of the cardinal responsibilities as worthy examiners is to know and detect all shades of examination malpractice, which include: (1) Impersonation, when a person acts in pretence or disguise to sit for an examination instead of the actual person; (2) Collusion, engaging a colleague to accomplish a task; and (3) Blocking of examiners etc. (Black \& Dylan, 1998; Baker, 2008; Mussawy, 2009; and Ibude et al., 2010).

Most often than not, there is this erroneous belief even by the Visual Artist/ lecturers that practical examination requires little or no supervision. Practical examinations just like the essay or theory, requires as much supervision and strictness; examination rules and regulations must be applied to the latter (Ibude et al., 2010). What you find in most cases in a typical examination is that as soon as question papers are distributed to candidates and attendance taken, the supervisor or invigilator takes leave, only to reappear once or twice and finally to collect the works. This practice has gradually affected the much emphasis on theoretical course. Evidence abound that practical examinations are bedevilled with malpractices or irregularities.

\section{CONCLUSION}

Excellent certification of students without the necessary skills, results in low productivity. The immediate consequence of wrong assessment of students is the wrong placement of grades and positions resulting to acceptance of unqualified, unsuitable candidates in workplaces. This paper has tried to investigate the factors responsible for the non-compliance with credible practical assessment in Visual Arts for quality certification, giving some insight into solutions that will help in stamping out these inhibiting/militating factors against the credible practical assessment in Visual Arts that guarantee quality assurance of our end products (students).

When more emphasis are laid on practical courses and standard practical test examination conducted, it will go a long way in solving the unemployment problem observed as possible fallout of assessment methods and emphasis paper qualification at the expense of practical practice which employs hands and brain for the development of our nation.

It is suggested that examination materials be provided at least a month to the commencement of examination, more time should be allotted to practical examinations, supervision of practical examination should be handled with more seriousness as it is with theoretical examination, and the joint assessment of practical examination works be introduced. Above all, it is further recommended that the product process assessment be adopted in Visual Arts.

In view of the above, it is recommended that scoring of Visual Art practical should be standardised and objectively infused to ensure high inter and intra-scorer reliabilities. It becomes imperative that some 
form of training be put in place to ensure the reliability of scoring during the conduct of practical and that scoring of practical examinations especially in the Visual Arts should not be left to one lecturer to assess since practical test is most often subjective. There is the need for joint assessment for fairness and good judgement.

Throughout the conduct of examination, it is proper to mention here that the conduct of practical test is the sole responsibility of the lecturers. Lecturers should, therefore, acquire the following for a successful conduct of practical examinations: (1) take attendance so as to know those who are dully registered for the examination, those present and absent with students signing appropriate column of the attendance; (2) in case where the examiners are to examine the process of work, the invigilator is to be present but not take the presence of the examiner as a collegial attitude; and (3) at the end of the examination, invigilators are to make sure that students sign out, all works secured and guarded jealously. This can be referenced or verified in the future for short comings that might crop up.

\section{References}

Adewale, G. (2004). "Examination Malpractice: A Stigma on School Effectiveness in Nigeria" in Nigeria Journal of Educational Research and Evaluation, 5(1).

Badmus, G.A. \& C.N. Omoifo. (1998). Essentials of Measurement and Evaluation in Education. Benin City: Osasu Publishers.

Baker, E.L. (2008). "Measuring $21^{\text {st }}$ Century Skills". Invited paper presented at the Universidad Complutense de Madrid, Madrid, Spain.

Black, Paul \& Wiliam Dylan. (1998). "Assessment and Classroom Learning" in Assessment in

\footnotetext{
${ }^{1}$ Statement: We, hereby, declare that this paper is our original work and not a product of plagiarism from any books or journals that have been published. The citation is stated and shown in the References. We confirm that this manuscript has not been published elsewhere and is not under consideration in whole or in part by another journal.
}

Education: Principles, Policy \& Practice, Volume 5, Issue 1 [March].

Darling-Hammond, Linda et al. (2013). Criteria for High-Quality Assessment. Stanford, CA: Stanford Center for Opportunity Policy in Education. Available online also at: https://edpolicy.stanford. edu/sites/default/files/publications [accessed in Auchi, Nigeria: November 10, 2016].

Gipps, C. (1994). Beyond Testing: Towards a Theory of Educational Assessment. London: Falmer.

Hornsby, O. (2001). Oxford Advanced Learners Dictionary of Current English. Oxford: Oxford University Press.

Ibude, Ikechukwu et al. (2010). "Probable Practical Evaluation in Visual Arts in Nigeria for Quality Certification" in International Journal of Research Development. Available online also at: http://globalacademicgroup.com/journals/ approaches [accessed in Auchi, Nigeria: November 10, 2016].

Jockov, Maja. (2016). "Presence of Contemporary Art Theory and Practical Work in Fine Arts Curricula in Grammar Schools" in Croatian Journal of Education, Vol.18, No.2, pp.223-237. Available online also at: file:///C:/Users/acer/ Downloads/Vol 18 Sp Ed No 220162124 Maja_Jockov.pdf [accessed in Auchi, Nigeria: April 15, 2017].

Maxwell, Graham. (2001). "Teacher Observation in Student Assessment" in Discussion Paper, Number 2 [October]. Available online also at: https://www.qcaa.qld.edu.au [accessed in Auchi, Nigeria: April 15, 2017].

Mehrens, W.A. \& I.J. Lehmann. (1975). Measurement and Evaluation in Education and Psychology. New York: Reinehart and Wiston, $2^{\text {nd }}$ edition.

Messick, S. (1994). “The Interplay of Evidence and Consequences in the Validation of Performance Assessments" in Educational Researcher, 23(2), pp.13-23.

Mussawy, Sayed Ahmad Javid. (2009). “Assessment Practices: Student's and Teachers' Perceptions of Classroom Assessment" in Master's Capstone Projects, 9. Available online also at: http:// scholarworks.umass.edu/cie_capstones/9 [accessed in Auchi, Nigeria: November 10, 2016].

Odili, J.N. \& E.P. Oghuvhu. (2008). Integrity in the Assessment of Students Performance in Examination. Asaba: Kremlin and Associates.

Osariyekemwen, D.N. (2003). "On the Job Assessment of Trained and Untrained Teachers in Oredo Local Government Area of Edo State". Unpublished PGDE Thesis. Abraka: Delta State University.

Park, Chris. (2003). "Engaging Students in the 
Learning Process: The Learning Journal" in Journal of Geography in Higher Education, Vol.27, No.2 [July], pp.183-199. Available online also at: http://www.lancaster.ac.uk/staff/gyaccp/ cjgh 272 05lores.pdf [accessed in Auchi, Nigeria: November 10, 2016].

Stake, R.E. (1969). "The Conference of Educational
Evaluation" in Teachers 'College Record, 68, April. Taylor, E.S. \& J.H. Tyler. (2012). "The Effect of Evaluation on Teacher Performance" in The American Economic Review, 102(7), pp.3628-3651.

Ughamadu, K.A. (1998). Educational Technology: Concepts, Principles, and Applications. Onitsha, Agbor: Kmensuo Educational Publisher. 


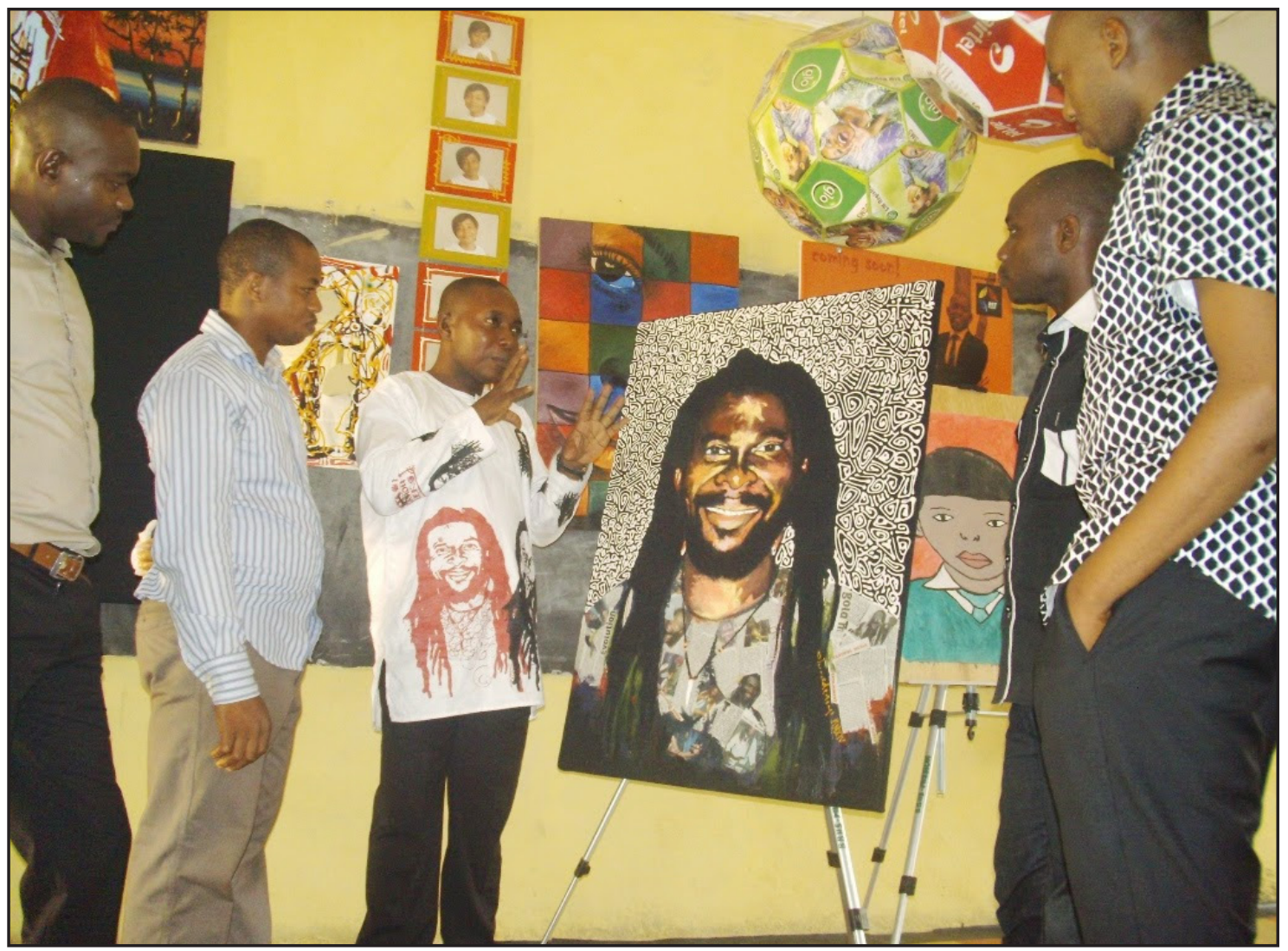

Visual Arts Education in Nigeria

(Source: http://baptistboyshighschool.blogspot.co.id, 15/4/2017)

TVET (Technical and Vocational Education and Training), which is the pivotal skill acquisition certification, has been taken as the key to unlocking the store house of the technological and economic growth of any nation. Therefore, attention and time must be given to the conduct of practical examinations leading to the acquisition of appropriate skills, abilities and competences for a quality, and credible practical certification. 